\title{
Lignin-Polyurethane Based Biodegradable Foam
}

\author{
Ravindra V. Gadhave, Prakash A. Mahanwar, Pradeep T. Gadekar \\ Department Polymer and Surface Engineering, Institute of Chemical Technology, Mumbai, India \\ Email: ravi.gadhave3@gmail.com
}

How to cite this paper: Gadhave, R.V., Mahanwar, P.A. and Gadekar, P.T. (2018) Lignin-Polyurethane Based Biodegradable Foam. Open Journal of Polymer Chemistry, 8, 1-10.

https://doi.org/10.4236/ojpchem.2018.81001

Received: November 27, 2017

Accepted: January 22, 2018

Published: January 25, 2018

Copyright (c) 2018 by authors and Scientific Research Publishing Inc. This work is licensed under the Creative Commons Attribution International License (CC BY 4.0).

http://creativecommons.org/licenses/by/4.0/ (c) (i) Open Access

\begin{abstract}
Natural sources like starch and lignin used during manufacturing of polyurethane (PU) foam have been used extensively from last decades and replaced petro-chemical based PU foam due to their lower environmental impact, easy availability, low cost and biodegradability. Bio-renewable sources, such as lignin which is an abundant, underutilized component of cellulosic biomass, constitute a rich source of polyol which are being considered as polyol for the production of "eco-friendly and bio-degradable" PU foam. Lignin was mainly used for production of high fungal degradable polyurethane foams, followed by elastomers as well as wood adhesives. This review paper will focus on the progress of research in lignin based polyurethane materials for foam application.
\end{abstract}

\section{Keywords}

Lignin, Polyurethane, Foam, Biodegradable, Polyol

\section{Introduction}

\subsection{Polyurethane Foams}

With numerous advantages, such as light weight, good heat insulation, excellent strength and corrosion resistance, electrical insulating properties, sound absorbing properties and low density, the consumption of polyurethane foams (PUFs) has grown rapidly, and the PUFs become indispensable part in our daily life [1]. The foams have been developed into many types and classes of products, such as insulation materials for apartment houses, cold stores, pipelines. PUFs are prepared by the polymerization of isocyanates with polyols, in which the reacting mixtures are foamed using one or more blowing agents.

The foam formation process consists of various steps:

- Mixing of the monomers and bubble nucleation, 
- Rise of the liquid foam,

- Phase separation, which leads to rapid modulus rise and cell opening, and formation of foamed elastomers [2] [3] [4].

\subsection{Bio-Waste from Industry}

Biomass obtained from industrial residues has considerable potential as a resource for industrial production [5] [6] [7]. Industrial residues ordinarily have homogeneous qualities and are cheap. Accordingly, products derived from residual materials are competitive in the market when characteristic properties of new products are similar or better than those derived from petroleum. Among numerous kinds of industrial residues, lignin is obtained on a large scale and is currently utilized only in a limited field [8]. Various types of industrial lignin are produced, not only as a byproduct of pulp and paper production [9] [10] [11] but also as bio-fuel production [12] [13].

\section{Need of Lignin as Raw Material in Polyurethane Foams}

Many kinds of rigid PU foams with different properties are widely used in construction industry, energy saving building and floating field. With the attention to the reduction of petroleum resources and the world environmental problems, however, the biodegradable polyurethane prepared by biomass, partially instead of polyol has aroused people's wide interests. Some researchers have studied how to synthesize PU foam by using modified starch and beeswax, but the price of these industrial raw materials is higher than that of the industrial lignin. The industrial lignin would have an obvious potential for using as the raw material of PU foam.

\section{Advantages of Lignin}

Lignin presents several advantages that make its utilization quite attractive in a wide range of applications.

Advantages:

- Readily available in huge quantities.

- If disposed as a waste, black liquor constitutes a serious environmental pollution hazard and therefore their valorization is of interest.

- High energy content due to its aromatic nuclei.

- Several reactive points available for chemical reactions [14].

\section{Type of Lignins}

Commercially available lignins are, most often, Kraft, soda and lignosulfonates associated to the corresponding most commonly used industrial processes for wood delignification and fibres isolation [15].

\section{Lignin Chemical Structure}

A renewable and promising source for sustainable chemicals and bio-based po- 
lymeric materials is lignin with random cross-linking of the sub-structural phenyl propane units, and the physical and chemical properties are highly dependent on the isolation processes. The higher order structure of lignin is fundamentally amorphous with phenylpropanoid units such as shown in Figure 1, p-coumaryl alcohol, coniferyl alcohol and/or synapyl alcohol cross-linked to produce a three-dimensional lignin polymer via a radical coupling process during its biosynthesis as shown in Figure 2.

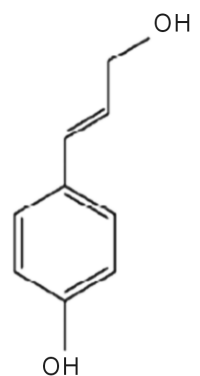

(a)<smiles>COc1cc(/C=C/CO)ccc1O</smiles>

(b)<smiles>COc1cc(/C=C/CO)cc(C)c1O</smiles>

(c)

Figure 1. Structure units of lignin (a) p-coumaryl alcohol (b) guaiacyl (c) synapyl alcohol.

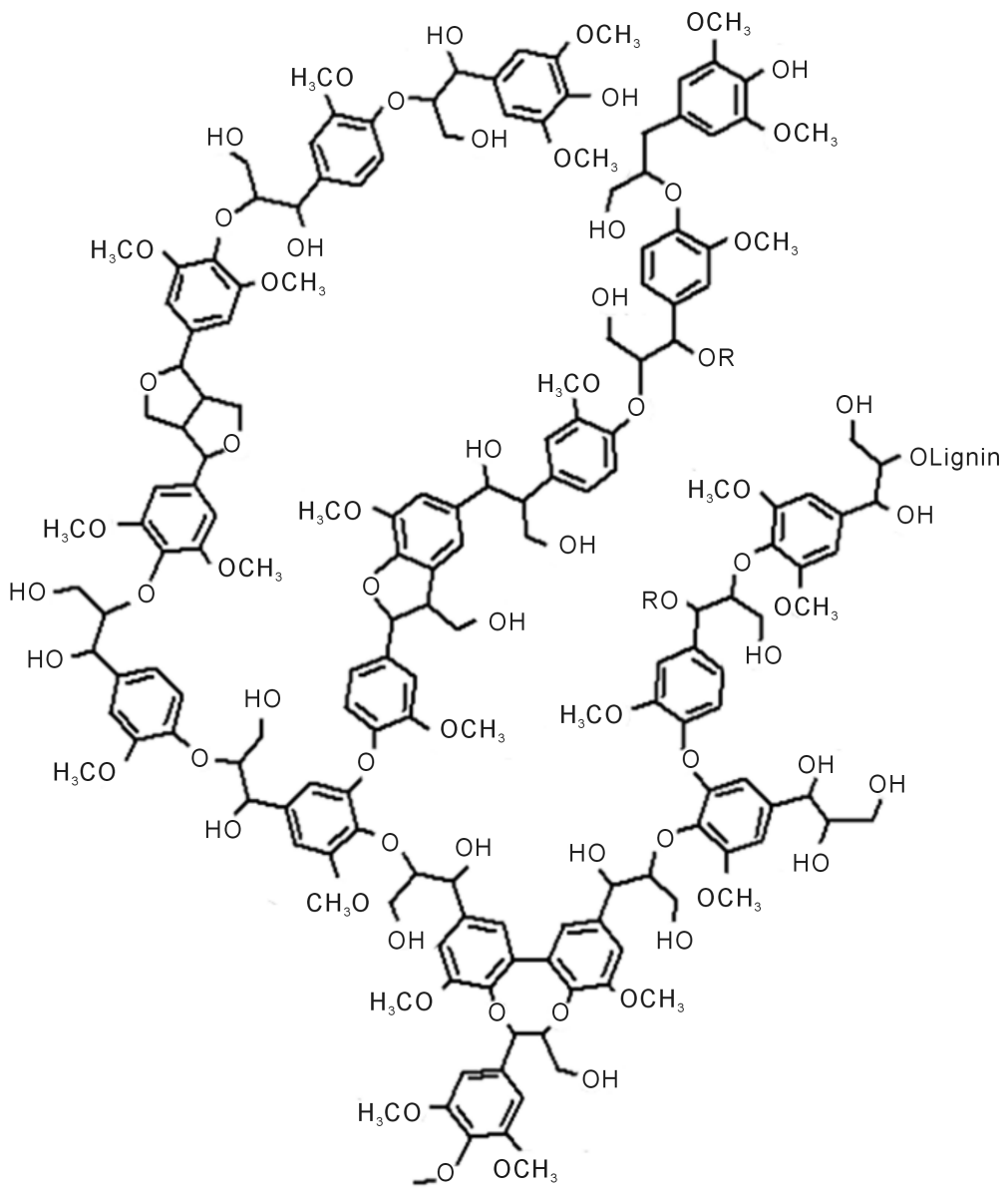

Figure 2. Three-dimensional structure of lignin polymer. 
Lignin is obtained as a byproduct of the chemical pulping industry. Various types of industrial lignin are obtained. Among them sodium linginosulfonate (NaLS) obtained from the sulfite pulping process is a polyelectrolyte, which is soluble in water and a certain number of organic solvents. [16] [17]. To increase the potential applications of lignin in polymeric materials, some chemical modifications have been developed [18] [19], but these add stages to the process and/or raise their costs considerably. Therefore, the direct use of industrial lignin is the most favorable option because it is a relatively cheap raw material. Unmodified lignin has poor stability [20] and difficult melt processing [21], which make its direct use uncompetitive. However, many studies have focused on the incorporation of lignin in polymer materials by blending it with synthetic or other biobased polymers [22] [23] [24] [25].

\section{Lignin Based Polyurethane Foam}

\subsection{Modified Lignin for PUF's}

Lignin had been successfully modified by three chemical methods: hydroxymethylation, epoxidation, and phenolation. Through these three methods, the number of reactive functional groups of lignins had increased, and the impurity had decreased. Hydroxymethylation lignin was the second highest among phenolic hydroxyl groups, followed by epoxidation lignin. By adding modified lignin into PUF material, it could not only increase the decomposition temperature of the foam but also remarkably improve its mechanical properties. Besides, phenolic lignin, which contains the highest content of phenolic hydroxyl group, represents fine dispersion when generating blends with polyether glycol, and it was almost completely dissolved in the polyether glycol. By adding modified lignin into the polyether glycol and according to the mechanical properties of the obtained foam material and the decomposition temperature, the optimum amount of modified lignin could be achieved, that was, $1 \mathrm{wt} \%$ of phenolated lignin and $3 \mathrm{wt} \%$ of exposidized lignin [26]. Crosslinkling reaction of polyurethane foam based on lignin-aminated polyol was studied by FTIRATR spectroscopic analysis. It was shown from the results that the crosslinking reaction was approximated to be a first-order reaction [27]. The lignin-based rigid polyurethane (PU) foams were prepared by separately adding the refined alkali lignin and alkali lignin modified by 3-chloro-1,2-epoxypropane to be instead of $15 \%$ of the polyether glycol in weight. The mechanical performances of the prepared PU foams in the experiments were better than those of the commercial PU foam. Especially, the lignin PU foam modified by 3-chloro-1,2-epoxypropane had the highest glass transition temperature which was indicating that it had a better thermal stability and could be applied in the heat resistant field [28] [29].

\subsection{Lignin with Other Biopolymer for PUF's}

Lignin-based polyurethanes with elastomeric properties had been successfully synthesized using a chemical system consisted on lignin, 4,4'-methylene-diphenylene 
diisocyanate (MDI) and polycaprolactone (PCL) of three different average-molecular weights (400, 750 and 1000) [30] also new types of PU foams derived from lignin and molasses were prepared. PU foams derived from this type of biopolymers could be used as insulation materials [31]. Combining lignin and castor oil as polyols for PU materials was promising [32] and also characterized PU materials based on sulfonated lignin and castor oil. The DMA results pointed out that the glass transition temperature of the samples increased and thus the degree of cross-linking with the increase of hydroxyl groups derived from different combinations of sulfonated lignin or sulfonated ligin oxypropylated or castor oil as polyols. Cinelli et al. [33] characterized flexible polyurethanes foams from liquefied lignin and two different chain extenders: castor oil and poly (propylene glycol) (PPG). The single use of unmodified or modified castor oil as a polyol is already consolidated [34]. Modified lignins had also been studied for this application [35] [36]. However, the combination of modified castor oil and unmodified industrial lignin showed an interesting opportunity for renewable and low cost polyols for preparation of PUF [37].

\subsection{Biodegradable PUF's}

Currently, the information concerning microbial degradation of commercial PU's in the environment is still limited. Lignin is a renewable material obtained in huge quantities as a by-product of the pulp industry. The ability of $A$. niger to degrade lignin based PU foams were studied in comparison with a conventional polyether-based one as control sample.

Lignin is generally described as highly resistant to biodegradation being mostly degrading by higher fungi via oxidative processes. Nevertheless, potential applications using lignin-degrading organisms and their enzymes have become attractive since they can provide both environmental friendly technologies for pulp and paper industry and added value to lignin-based products that can be presented as more degradable. Moreover, it had been recently reported that the incorporation of lignin at amounts lower than $10 \%(\mathrm{w} / \mathrm{w})$ were able to increase biodegradability of commonly used polyurethanes [38] [39].

Thus, the incorporation of biobased structural units into the synthetic PU foams by using lignin-based polyols as a replacement of commercial ones could be an interesting strategy of producing a polymer susceptible to undergo easily microbial degradation, thus resulting in an enhanced biodegradability.

\subsection{Flame-Retardant PUF's}

Lignin, a natural macromolecule containing substantial aromatic rings and abundant hydroxyl groups, were firstly chemically grafted with phosphorus-nitrogen-containing groups via liquefaction-esterification-salification process to prepare lignin-based phosphate melamine compound (LPMC). And then the LPMC which had remaining hydroxyl groups were used to substitute parts of polyols and copolymerize with isocyanate to produce lignin-modified-PU foam 
with excellent flame retardancy [40].

\section{Benefit of Lignin in PU Foam (PUFs)}

PUFs have accounted for two-thirds of the total PU demand in the literature [41] used for example in equipment manufacture, freeze sectors, aviation construction, and automotive production, and become an indispensable part of our daily living because of their light weight, good insulation, excellent corrosion resistance, and mechanical properties [42]-[48]. PUFs are usually inflammable and brittle. Therefore, it was indispensable to add certain retardant additives as compounds to improve their thermal and mechanical properties.

- It had been reported that PUFs blended with lignin displayed more excellent mechanical property and, at the same time, increased decomposition temperature, which also indicated that lignin-based PUFs could successfully replace currently used PUF materials on the market [49].

- There were two ways to add lignin into foam materials.

- One way was as an additive-lignin was added into foams directly.

- Another way was as a reaction agent-lignin was a substitute for a part of polyol to prepare PUFs [50] [51].

\section{Conclusion}

Lignin is an easily available, cost-effective and renewable biomaterial widespread in plants. Lignin is a byproduct of the paper industry, and exists in the black liquor of the pulping industry. Addition of lignin in the application of polyurethane not only is an effective method in using renewable biomass energy, but also enhances properties of polyurethane like excellent mechanical, heat-resistant and compression performance and aging-resistant performance [52]. The use of biobased raw materials can significantly contribute to sustainable development due to bio-degradability and low toxicity of the resulting products [53] [54]. At low concentration of lignin, the PU materials can be easily obtained, whereas it is difficult to get lignin-derived PU materials with high lignin concentration. Thus, complete replacement of lignin to polyol is a research focus [55].

\section{Futuristic Research}

Remarkable, from the practical point of view, further research on the compatibility between the lignin and the PU matrix should be enhanced. From the academic point of view, it is very necessary to probe functional mechanism of lignin with other additives in PU polymers, chemical modification of lignin and complete replacement of lignin to polyol will be a research focus.

\section{References}

[1] Huo, S.-P., Nie, M.-C., Kong, Z.-W., Wu, G.-M. and Chen, J. (2012) Crosslinking Kinetics of the Formation of Lignin-Aminated Polyol-Based Polyurethane Foam. Journal of Applied Polymer Science, 125, 152-157. https://doi.org/10.1002/app.35401 
[2] Daniel, K. and Vahid, S. (1991) Handbook of Polymeric Foams and Foam Technology. Oxford University Press, New York.

[3] Neff, R.A. and Macosko, C.W. (1996) Simultaneous Measurement of Viscoelastic Changes and Cell Opening during Processing of Flexible Polyurethane Foam. Rheologica Acta, 35, 656-666. https://doi.org/10.1007/BF00396514

[4] Yasunaga, K., Neff, R.A. and Zhang, X.D. (1996) Study of Cell Opening in Flexible Polyurethane Foam. Journal of Cellular Plastics, 32, 427-448. https://doi.org/10.1177/0021955X9603200502

[5] Gandini, A. and Belgacem, N.M. (1998) Recent Advances in the Elaboration of Polymeric Materials Derived from Biomass Components. Polymer International, 47, 267-276. https://doi.org/10.1002/(SICI)1097-0126(199811)47:3<267::AID-PI9>3.0.CO;2-X

[6] Gandin, A., Belgacem, N.M., Guo, Z.X. and Montanari, S. (2002) Lignins as Macromonomers for Polyesters and Polyurethanes. In: Hu, T.Q., Ed., Chemical Modification, Properties, and Usage of Lignin, Academic/Plenum, New York, 57-80. https://doi.org/10.1007/978-1-4615-0643-0_4

[7] Hatakeyama, H. (2002) Polyurethane Containing Lingin. In: Hu, T.Q., Ed., Chemical Modification, Properties and Usage of Lignin, Academic/Plenum, New York, 41-56. https://doi.org/10.1007/978-1-4615-0643-0_3

[8] Hatakeyama, H. and Hatakeyama, T. (2010) Lignin Structure, Properties and Applications. In: Abe, A., Dusek, K. and Kobayashi, S., Eds., Biopolymers, Vol. 232. Advances in Polymer Science, Springer, New York, 1-63.

[9] Sarkanen, K.V. and Ludwig, C.H. (1971) Lignins, Occurrence, Formation, Structure and Reactions. Wiley-Interscience, New York.

[10] Lin, S.Y. and Dence, C.W., Eds. (1992) Methods in Lignin Chemistry. Springer Series in Wood Science. Springer, Berlin, Heidelberg, 527-548.

https://doi.org/10.1007/978-3-642-74065-7

[11] Hu, T.Q. (2008) Characterization of Lignocellulosic Materials. Blackwell, Oxford. https://doi.org/10.1002/9781444305425

[12] Hatakeyama, H., et al. (2013) Glass Transition Temperature of Polyurethane Foams Derived from Lignin by Controlled Reaction Rate. Journal of Thermal Analysis and Calorimetry, 114, 1075-1082. https://doi.org/10.1007/s10973-013-3132-1

[13] Hatakeyama, H., Tsujimoto, Y., Ja. Zarubin, M., Krutov, S.M. and Hatakeyama, T. (2010) Thermal Decomposition and Glass Transition of Industrial Hydrolysis Lignin. Journal of Thermal Analysis and Calorimetry, 101, 289-295. https://doi.org/10.1007/s10973-010-0698-8

[14] Cateto, C.A.B. (2008) Lignin-Based Polyurethanes, Characterisation, Synthesis and Applications. Dissertation, Universidade do Porto (FEUP), Porto.

[15] Gadhave, R.V., Mahanwar, A. and Gadekar, T. (2017) Bio-Renewable Sources for Synthesis of Ecofriendly Polyurethane Adhesives-Review. Open Journal of Polymer Chemistry, 7, 57-75. https://doi.org/10.4236/ojpchem.2017.74005

[16] Sarkanen, K.V. and Ludwig, C.H. (1971) Lignins, Occurrence, Formation, Structure and Reactions. John Wiley \& Sons, Inc., New York.

[17] Wang, H., Ni, Y., Jahan, M.S., Liu, Z. and Schafer, T. (2011) Stability of Cross-Linked Acetic Acid Lignin-Containing Polyurethane. Journal of Thermal Analysis and Calorimetry, 103, 293-302. https://doi.org/10.1007/s10973-010-1052-x

[18] Duval, A. and Lawoko, M. (2014) A Review on Lignin-Based Polymeric, Micro- and Nano-Structured Materials. Reactive and Functional Polymers, 85, 78-96. 
https://doi.org/10.1016/j.reactfunctpolym.2014.09.017

[19] Kandula, M., Schwenke, T., Friebel, S. and Salthammer, T. (2015) Effect of Ball Milling on Lignin Polyesterification with $\varepsilon$-Caprolactone. Holzforschung, 69, 297-302. https://doi.org/10.1515/hf-2014-0053

[20] Braun, J.L., Holtman, K.M. and Kadla, J.F. (2005) Lignin-Based Carbon Fibers, Oxidative Thermostabilization of Kraft Lignin. Carbon, 43, 385-394. https://doi.org/10.1016/j.carbon.2004.09.027

[21] Norberg, I., Nordström, Y., Drougge, R., Gellerstedt, G. and Sjöholm, E. (2013) A New Method for Stabilizing Softwood Kraft Lignin Fibers for Carbon Fiber Production. Journal of Applied Polymer Science, 128, 3824-3830. https://doi.org/10.1002/app.38588

[22] Lora, J. (2008) Industrial Commercial Lignins: Sources, Properties and Applications. In: Belgacem, M.N. and Gandini, A., Eds., Monomers, Polymers and Composites from Renewable Resources, Elsevier, Amsterdam, Chapter 10, 225-241.

[23] Gordobil, O., Delucis, R., Egüés, I. and Labidi, J. (2015) Kraft Lignin as Filler in PLA to Improve Ductility and Thermal Properties. Industrial Crops and Products, 72, 46-53. https://doi.org/10.1016/j.indcrop.2015.01.055

[24] Schorr, D., Diouf, P.N. and Stevanovic, T. (2014) Evaluation of Industrial Lignins for Biocomposites Production. Industrial Crops and Products, 52, 65-73. https://doi.org/10.1016/j.indcrop.2013.10.014

[25] Spiridon, I., Leluk, K., Resmerita, A.M. and Darie, R.N. (2015) Evaluation of PLA-Lignin Bioplastics Properties before and after Accelerated Weathering. Composites Part B: Engineering, 69, 342-349. https://doi.org/10.1016/j.compositesb.2014.10.006

[26] Yang, L., Wang, X., Cui, Y., et al. (2014) Modification of Renewable Resources-Lignin-By Three Chemical Methods and Its Applications to Polyurethane Foams. Polymers for Advanced Technologies, 25, 1089-1098.

https://doi.org/10.1002/pat.3356

[27] Calvo-Correas, T., Gabilondo, N., Alonso-Varona, A., Palomares, T., Corcuera, M.A. and Eceiza, A. (2016) Shape-Memory Properties of Crosslinked Biobased Polyurethanes. European Polymer Journal, 78, 253-263. https://doi.org/10.1016/j.eurpolymj.2016.03.030

[28] Luo, X., Mohanty, A. and Misra, M. (2013) Lignin as a Reactive Reinforcing Filler for Water-Blown Rigid Biofoam Composites from Soy Oil-Based Polyurethane. Industrial Crops and Products, 47, 13-19. https://doi.org/10.1016/j.indcrop.2013.01.040

[29] Cheradame, H., Detoisien, M., Gandini, A., Pla, F. and Roux, G. (1989) Polyurethane from Kraft Lignin. Polymer International, 21, 269-275.

https://doi.org/10.1002/pi.4980210314

[30] García, A., Erdocia, X., González, M.A. and Labidi, J. (2012) Effect of Ultrasound Treatment on the Physicochemical Properties of Alkaline Lignin. Chemical Engineering and Processing: Process Intensification, 62, 150-158. https://doi.org/10.1016/j.cep.2012.07.011

[31] Hatakeyama, H., Kosugi, R. and Hatakeyama, T. (2008) Thermal Properties of Lignin- and Molassesbased Polyurethane Foams. Journal of Thermal Analysis and Calorimetry, 92, 419-424. https://doi.org/10.1007/s10973-007-8963-1

[32] De Oliveira, F.D., Ramires, E.C., Frollini, E. and Belgacem, M.N. (2015) Lignopolyurethanic Materials Based on Oxypropylated Sodium Lignosulfonate and Castor Oil Blends. Industrial Crops and Products, 72, 77-86. 
https://doi.org/10.1016/j.indcrop.2015.01.023

[33] Cinelli, P., Anguillesi, I. and Lazzeri, A. (2013) Green Synthesis of Flexible Polyurethane Foams from Liquefied Lignin. European Polymer Journal, 49, 1174-1184. https://doi.org/10.1016/j.eurpolymj.2013.04.005

[34] Yeganeh, H. and Mehdizadeh, M.R. (2004) Synthesis and Properties of Isocyanate Curable Millable Polyurethane Elastomers Based on Castor Oil as a Renewable Resource Polyol. European Polymer Journal, 40, 1233-1238. https://doi.org/10.1016/j.eurpolymj.2003.12.013

[35] Nada, A.-A.M.A., Yousef, M.A., Shaffei, K.A. and Salah, A.M. (1998) Infrared Spectroscopy of Some Treated Lignins. Polymer Degradation and Stability, 62, 157-163. https://doi.org/10.1016/S0141-3910(97)00273-5

[36] Zhang, C., Wu, H. and Kessler, M.R. (2015) High Bio-Content Poly Urethane Composites with Urethane Modified Lignin as Filler. Polymer, 69, 52-57. https://doi.org/10.1016/j.polymer.2015.05.046

[37] Mohamed, H.A., Badran, B.M., Rabie, A.M. and Morsi, S.M.M. (2014) Synthesis and Characterization of Aqueous (Poly Urethane/Aromatic Polyamide Sulfone) Copolymer Dispersions from Castor Oil. Progress in Organic Coatings, 77, 965-974. https://doi.org/10.1016/j.porgcoat.2014.01.026

[38] Amaral, J.S., Sepulveda, M., Cateto, C.A., Farnandes, I.P., Rodrigues, A.E., Belgacem, M.N. and Barreiro, M.F. (2012) Fungal Degradation of Lignin-Based Rigid Polyurethane Foams. Polymer Degradation and Stability, 97, 2069-2076. https://doi.org/10.1016/j.polymdegradstab.2012.03.037

[39] Ignat, L., Ignat, M., Ciobanu, C., Doroftei, F. and Popa, V.I. (2011) Effects of Flax Lignin Addition on Enzymatic Oxidation of Poly(Ethylene Adipate) Urethanes. Industrial Crops and Products, 34, 1017e28.

[40] Zhu, H.B., Peng, Z.M., Chen, Y.M., Li, G.Y., Wang, L., Tang, Y., Pang, R., Ul Haq Khan, Z. and Wan, P.Y. (2014) Preparation and Characterization of Flame Retardant Polyurethane Foams Containing Phosphorus-Nitrogen-Functionalized Lignin. RSC Advances, 4, 55271-55279. https://doi.org/10.1039/C4RA08429B

[41] Tay, G.S., Ong, L.N. and Rozman, H.D. (2012) Mechanical Properties and Fire Retardant Behavior of Polyurethane Foam Reinforced with Oil Palm Empty Fruit Bunch. Journal of Applied Polymer Science, 125, 158-164.

https://doi.org/10.1002/app.35568

[42] Draye, A.C. and Tondeur, J.J. (1999) Temperature Effect on Alcohol-Isocyanate Kinetics. Reaction Kinetics and Catalysis Letters, 66, 319-324. https://doi.org/10.1007/BF02475807

[43] Thirumal, M., Khastgir, D., Singha, N.K., Manjunath, B.S. and Naik, Y.P. (2008) Effect of Foam Density on the Properties of Water Blown Rigid Polyurethane Foam. Journal of Applied Polymer Science, 108, 1810-1817.

[44] Amaral, J.S., Sepúlveda, M. and Cateto, C.A. (2012) Fungal Degradation of Lignin-Based Rigid Polyurethane Foams. Polymer Degradation and Stability, 97, 2069-2076. https://doi.org/10.1016/j.polymdegradstab.2012.03.037

[45] Huo, S.P., Nie, M.C. and Kong, Z.W. (2012) Crosslinking Kinetics of the Formation of Lignin-Aminated Polyol-Based Polyurethane Foam. Journal of Applied Polymer Science, 125, 152-157. https://doi.org/10.1002/app.35401

[46] Landrock, A.H. (1995) Handbook of Plastic Foams: Types, Properties, Manufacture, and Applications. Noyes Publications, Park Ridge, NJ.

[47] Hirschler, M.M. (2008) Polyurethane Foam and Fire Safety. Polymers for Advanced 
Technologies, 19, 521-529. https://doi.org/10.1002/pat.1092

[48] Xu, Z.B., Kong, W.W., Zhou, M.X. and Peng, M. (2010) Effect of Surface Modification of Montmorillonite on the Properties of Rigid Polyurethane Foam Composites. Chinese Journal of Polymer Science, 28, 615-624.

https://doi.org/10.1007/s10118-010-9111-0

[49] Stewart, D. (2008) Lignin as a Base Material for Materials Applications, Chemistry, Application and Economics. Industrial Crops and Products, 27, 202-207. https://doi.org/10.1016/j.indcrop.2007.07.008

[50] Doherty, W., Halley, P., Edye, L., Rogers, D., Cardona, F., Park, Y. and Woo, T. (2007) Studies on Polymers and Composites from Lignin and Fiber Derived from Sugar Cane. Polymers for Advanced Technologies, 18, 673-678. https://doi.org/10.1002/pat.879

[51] Yoshida, H., Morck, R., Kringstad, K.P. and Hatakeyama, H. (1987) Kraft Lignin in Polyurethanes I. Mechanical Properties of Polyurethanes from a Kraft Lignin-Polyether Triol-Polymeric MDI System. Journal of Applied Polymer Science, 34, 1187-1198. https://doi.org/10.1002/app.1987.070340326

[52] Liu, Z.M., Yu, F., Fang, G.Z. and Yang, H.J. (2009) Performance Characterization of Rigid Polyurethane Foam with Refined Alkali Lignin and Modified Alkali Lignin. Journal of Forestry Research, 20, 161-164.

https://doi.org/10.1007/s11676-009-0028-9

[53] Tavares, L.B., Boas, C.V., Schleder, G.R., Nacas, A.M., Rosa, D.S. and Santos, D.J. (2016) Bio-Based Polyurethane Prepared from Kraft Lignin and Modified Castor Oil. eXPRESS Polymer Letters, 10, 927-940. https://doi.org/10.3144/expresspolymlett.2016.86

[54] Daemi, H., Barikani, M. and Barmar, M. (2013) Highly Stretchable Nanoalginate Based Polyurethane Elastomers. Carbohydrate Polymers, 95, 630.

[55] Zhang, Q., Zhang, G., Xu, J., et al. (2015) Recent Advances on Ligin-Derived Polyurethane Polymers. Reviews on Advanced Materials Science, 40, 146-154. 